\title{
Effect of Educational Program about Nurse Managers' Performance Appraisal during COVID19 on Staff Nurses' Satisfaction and Motivation
}

\author{
${ }^{1}$ Amal Hamdy Abou Ramadan, ${ }^{2}$ Walaa Mostafa Eid \\ ${ }^{1,2}$ Lecturers of Nursing Administration, Faculty of Nursing, Tanta University, Egypt.
}

\begin{abstract}
:
Background: COVID-19 creates a negative impact across healthcare sectors and performance appraisal is one of the most areas in nursing management which is significantly affected. Aim of the study: This study aimed to explore effect of educational program about nurse managers' performance appraisal during COVID19 on staff nurses' satisfaction and motivation. Subjects and method: Quasi experimental research design was utilized. The study was conducted in all departments at cardiology center at El Mehallah El Kobra city. All ( $\mathrm{n}=30)$ nurse managers and all $(n=183)$ staff nurses worked in the same setting are involved in the study. Four tools were used to gather the data: nurse managers' role in managing performance appraisal during COVID 19 self- reporting questionnaire, nurse managers' performance appraisal knowledge questionnaire, staff nurses' satisfaction with performance appraisal scale and staff nurses' job motivation scale. Results: All nurse managers had low level in their role in managing performance appraisal during COVID- 19 and in total level of knowledge preprogram compared to the majority and nearly two-thirds had high level post program in role and knowledge, respectively. Statistically significant improvement was found in levels of staff nurses' satisfaction with performance appraisal and motivation post program implementation. Conclusion: Educational program for nurse managers on performance appraisal during COVID 19 plays a vital role in increasing staff nurses' satisfaction and motivation. Recommendation: Prime importance to modify performance appraisal forms to adapt to any changing that occurs in environment and receives continuous feedback from staff nurses about their satisfaction with present performance appraisal system.
\end{abstract}

Key words: Motivation ,Nurse Managers, Performance appraisal during COVID-19, Staff nurses' satisfaction

Vol. 20 No. 1 February, 2021 


\section{Introduction}

COVID-19 pandemic created a negative impact across all healthcare sectors. Nurse managers found themselves in big challenges. They had to adapt to novel situations, make critical decision, and ensure safe delivery of care. Also, they are responsible for engagement of their staff nurses that struggle to cope with the new working environment especially staff nurses taking new tasks and roles that not done before. Nurse managers found that most of the components of performance reviews have been discarded and unsuitable during the coronavirus crisis. So, how performance appraisal done in current situation of COVID 19 becomes a critical issue that have to be considered in the present time of crises ${ }^{(1-3)}$.

Nurse managers tend to restructure the appraisal process structure refocusing on staff nurses' role in achieving the new objectives and retain a balance between the staff nurses' safety and wellbeing, as well as their efficiency and productivity during the pandemic (4). Staff nurses' performance appraisal at the time of COVID-19 crises is not only an opportunity to evaluate current work, but it is also an opportunity to reset priorities and emphasis on what needs to be achieved in the coming months of the pandemic. Without guidance on staff nurses' new key priorities, they can be left demotivated and unengaged, which negatively impacts their satisfaction and output ${ }^{(5)}$.

Performance appraisal as a formally planned system is a continuous process that measure inputs and outcomes of staff nurses directing on their strengths, weaknesses and discovering how the staff nurses performing in their job. It includes organizational processes such as performance measurement, objective formation, and reward management ${ }^{(6)}$. Review of performance is an important career development tool for the managers and staff nurses in which the managers guide staff nurses on the track to corporate advancement, and staff nurses get a clearer understanding of what is expected from their daily job duties goals ${ }^{(7)}$. The information obtained through the assessment provides foundations for training and growth of existing staff, as well as motivating and upholding a quality workforce by adequately and accurately rewarding their performance ${ }^{(8)}$.

Managing performance appraisal effectively during COVIDE 19 requires the managers to create positive environment and plan for appraisal accurately. Nurse managers enhance positive environment through avoiding staff nurses criticism, continuing 
conversations and discussions with staff nurses what is expected from them, what is need to improve, and what support might be needed to help achieve their new role. Then creating a comprehensive plan for staff nurses' development and giving nurses' achievements to strive for will inspire a higher level of competence. Once staff nurses' performance is measured against the set goals and objectives, a need can be identified about the future strategies of staff nurses' motivation ${ }^{(9,10)}$. Motivation is the process that empowers staff nurses and pushes them to achieve their goals. Performance appraisal that designed appropriately have a strong effect on success of organization ${ }^{(7)}$. The management has to pay more attention to the level of staff nurses' satisfaction with the performance appraisal process to achieve motivation which in turn leads to better performance and proficiency ${ }^{(11)}$.

Staff nurses' performance appraisal also can act as incentive to improve their efficiency. When staff nurses see their goals evidently defined, their performance challenges identified and career enrichment solutions in place to help advance their role in treating COVID patients, the effect is to inspire the staff nurses to achieve those goals $^{(7)}$. If managers use the appraisal inappropriately, cause disastrous effects (12). In this period of slowdown and uncertainty the role of manager becomes quite essential to provide guidance, build strategy and implement support to the staff nurses' work $^{(13)}$. Therefore, educational program become urgent for helping nurse managers to be aware about new approaches and strategies for performance evaluation to promote nurses' performance, productivity, and motivation.

\section{Significance of the study}

COVID-19 significantly impacted hospital cardiology services in different ways and posed new challenges in staff nurses' role $^{(14)}$. Unanticipated stress on the cardiac staff nurses' role performance, systems of nursing care, and critical resource supplies are presented ${ }^{(15)}$. The lack of satisfaction with the performance appraisal process in organizations is considered as one of the symptoms of the organizational diseases (16). So, improving the performance evaluation process for motivating, reassuring, and satisfying staff nurses come to be imperative to enhance their job performance and productivity. Because of the complexity ever changing and challenging nature of the evaluation methods, the educational program for 
nurses managers help them to manage appraisal at this changing time, increase their responsiveness to overcome the appraisal problems of subjectivity and unfairness, inappropriate feedback.

\section{Aim of the study}

This study aimed to explore effect of educational program about nurse managers' performance appraisal during COVID19 on staff nurses' satisfaction and motivation

\section{Research hypothesis}

1- After implementing educational program, it is expected that managing performance appraisal during COVID 19 by nurse managers will be improved.

2- Nurses' motivation and satisfaction level will be improved.

\section{Subjects and Method:}

Study design: Quasi experimental research design was utilized.

Study Setting: Study was conducted in all departments at Cardiology Center at El Mehallah El Kobra city with capacity of 140 beds. The setting is one from Ministry of Health and Population sectors that provides combination of profit and nonprofit services. Units understudy included CCU, open heart surgery, emergency, cardiac catheterization, and inpatient wards.
Subjects: All ( $\mathrm{N}=30)$ nurse managers and all $(\mathrm{N}=183)$ staff nurses worked in the above-mentioned hospital.

Tools: four tools were exploited to gather the study data.

Tool (1): Nurse Managers Role in Managing Performance Appraisal during COVID 19 Self- reporting Questionnaire

This tool developed by the researchers guided by Deligiannis (2020) ${ }^{(5)}$, Alvear and David (2006) $)^{(\mathbf{1 7})}$ to assess nurse managers role in managing performance appraisal during time of covid 19 . It included three subscales: creating positive environment for appraisals during covid 19 (6 items), planning the performance appraisal during covid 19 (9 items), and performance review during covid 19 (10 items) besides, seven items related to nurse manager' personal characteristics. The subjects' response were on 3-points Likert scaling varying from 1 (never done) to 3 (always done). Levels of nurse managers role in managing performance appraisal statistically represented based on the cut of value into three levels; $\geq 75 \%$ as high level; $<75 \%-60 \%$ as moderate level; $<60 \%$ as low role level. 
Tool (II): Nurse Managers

\section{Performance Appraisal Knowledge}

\section{Questionnaire}

This tool was developed by the researcher guided by Deligiannis (2020) ${ }^{(5)}$, Moradi et al (2017) ${ }^{(18)}$, Saeedi et al (2014) ${ }^{(19)}$, Aggarwal and Thakur (2013) ${ }^{(20)}$ to assess nurse managers' knowledge about performance appraisal. It consisted of 25 multiple choice and true and false questions covering the following: performance appraisal basic concepts (4 items), purpose of performance appraisal (4 items), principles of performance appraisal (4 items), methods of performance appraisal (4 items) , Strategies used to appraise staff during COVID 19 (5 items), and limitation to effective performance appraisal during COVID 19 (4 items). The scoring system for the questionnaire sheet consisted of score one for correct answer and zero for wrong answer. The scoring levels were statistically arranged at cut point as $>75 \%$ for high level of knowledge, moderate level $60-75 \%$ and low level of knowledge $<60 \%$.

Tool (III): Staff Nurses' Satisfaction with Performance Appraisal scale.

The adopted performance appraisal satisfaction scale was developed by
Bekele et al (2014) ${ }^{(6)}$ contained 12 items to assess staff nurses' satisfaction with performance appraisal during COVID 19. Staff nurses rated their responses by using 5 points Likert scale ranging from 1 (strongly disagree) to 5 (strongly agree). Levels of satisfaction with performance appraisal represented statistically according to cut off point into; high level $>75 \%$, moderate level $60-75 \%$ and low level of satisfaction level $<60 \%$.

\section{Tool (IV): Staff Nurses' Job Motivation}

\section{Scale.}

This tool developed by researcher based on Warr and Clapperton (2010) ${ }^{(21)}$ and Cameron and Pierce (1994) ${ }^{(22)}$. It consisted of 12 items to assess staff nurses' job motivation. Nurses rated their responses by using 5-point Likert scale ranging from 1 (never) to 5 (always). Staff nurses' job motivation levels statistically represented based on the cut of value as > $75 \%$ high level; $60-75 \%$ as moderate level; and $<60 \%$. as low motivation level.

\section{Method}

Official permission was obtained from the authoritative personnel to conduct the study. 


\section{Ethical consideration}

- Informed consent was gotten from nurse managers and staff nurses before data gathering.

- subjects' anonymity was considered and assured that the data is confidential and used only for research purposes.

\section{Validity and reliability}

Panels of 5 experts in field of nursing administration revise and check content validity of tools. The necessary modifications were done based on their opinion through omitting and clarify some items. A pilot study was conducted on 10 percent of the study sample (3 nurse manager and 19 staff nurse). Cronbach Coefficient Alpha test was used to measure tools' reliability; it was 0.83 for tool $1 ; 0.94$ for tool II; 0.91 for tool III and; 0.86 for tool IV.

\section{Field work}

Data was collected in four phases.

\section{1- Assessment phase:}

- Tool I, II were distributed by researcher to assess nurse manager role in managing performance appraisal during COVID-19 and their knowledge levels about performance appraisal. Tool III and tool IV used to assess staff nurse's satisfaction with performance appraisal and assess their job motivation.

- The data collected during subjects' morning shift. Researchers were present during collection of data for any needed guidance and clarification.

- The tools collected personally by researcher immediately after completed. The administration time for filling the questionnaire sheet was approximately $15-20$ minutes for tool (I, II) and approximately 10 minutes for (tool III, IV).

\section{2-Planning phase:}

- Program objectives, content and methods of teaching were selected after careful assessment of nurse managers' needs.

- The teaching methods used were lecture, group discussion and examples from life and work situation with the aids of data show and handout

\section{3-Implementation phase:}

- All nurse managers divided into five groups. Every group had one session every day for 3 days, each session lasted an hour.

- The program cover points on performance appraisal basic concepts, purpose, principles, methods, limitations and strategies used to manage performance appraisal at COVID-19. 
- The program sessions were held in conference room at the last hour in nurse managers shift to be free after completed their work. The program educational sessions lasted two months from first of June to end of July 2020.

\section{2- Evaluation phase:}

- Tool II was utilized immediacy after the program implementation to assess the changes in nurse managers level of knowledge. Tools (I,III and IV) utilized one month later post program implementation because the performance appraisal officially done monthly in the study setting (cardiology center) to assess nurse managers role in managing appraisal and levels of staff nurses' satisfaction with performance appraisal and their job motivation post program

\section{Data analysis}

Data were fed to the computer and analyzed using IBM SPSS software package version 20.0. (Armonk, NY: IBM Corp). Qualitative data were described using number and percent. Quantitative data were described using mean, standard deviation. Significance of the obtained results was judged at the $5 \%$ level. Chisquare test was used to determine differences between variables, and Pearson coefficient test to correlate between two normally distributed quantitative variable.

\section{Results:}

Table (1) shows distribution of study samples according to personal characteristics. The table reveals that $80 \%$ of nurse managers had more than forty years with mean age $40.0 \pm 1.49$. High percent $(70 \%)$ of them had years of experience between 5-10 years with mean years of experience $7.63 \pm 2.19$. Moreover, all (100\%) nurse managers were female and married. About quarter $(26.7 \%)$ of them worked in cardiac catheterization unit while the majority $(86.6 \%)$ had bachelor's degree, and all $(100 \%)$ not attend any training programs about performance appraisal.

For staff nurses, the majority (88\%) were in the age group 20-25 years with mean age $25.45 \pm 2.99$. Nearly half $(49.2 \%)$ of staff nurses had years of experience between 5-10 years with mean years of experience $5.57 \pm 2.38$. Furthermore, the majority $(92.8 \%, 82.5 \%)$ of them were married and female, respectively. Nearly quarter $(23.5 \%)$ of staff nurses worked in cardiac care unit (CCU) and more than one-third $(37.7 \%)$ of them had bachelor's degree.

Figure (1) shows levels of nurse managers overall role in managing performance 
appraisal during COVID- 19 pre and post program implementation. All nurse managers had low level in their role in managing performance appraisal preprogram compared to the majority had high level post program implementation.

Table (2) illustrates levels of nurse managers role subscales in managing performance appraisal during COVID- 19 pre and post program implementation. There is statistically significant improvement in all nurse managers' role in management performance appraisal during COVID- 19 post program implementation. Pre- program, all (100\%) nurse managers had low level in all subscale of their role in managing performance appraisal during COVID- 19 compared to $80 \%, 76.7 \%$, 66.7 had high level in performance review, planning the performance appraisal and creating positive environment for appraisal respectively post program implementation.

Figure (2) shows nurse managers' total knowledge levels about performance appraisal pre and post program implementation. The figure shows that all nurse managers had low level of knowledge about performance appraisal management during COVID- 19 preprogram implementation compared to nearly two third had high level post program implementation.
Table (3) shows Nurse managers' knowledge levels about performance appraisal pre and post program implementation. The table shows statistically significant improvement in nurse managers' levels of knowledge post program implementation in all items of performance appraisal. Preprogram, knowledge level was low ranged from 93.3\%- $100 \%$ in all items of performance appraisal. However, post program high percent $(76.6 \%, 70 \%)$ of nurse managers had high level of knowledge regarding strategies to manage appraisal during COVID -19 and methods, respectively.

Table (4) shows levels of staff nurses' satisfaction and motivation pre and post program implementation. Statistically significant difference found between levels of staff nurses' satisfaction with performance appraisal and motivation pre and post program implementation. Preprogram, majority $(90.7 \%, 81.96 \%)$ of staff nurses had low level of satisfaction with performance appraisal and motivation, respectively while postprogram implementation of performance appraisal around two-third (65.57\%, $64.4 \%$ ) of staff nurses had high level of satisfaction with performance appraisal and motivation respectively. 
Table (5) shows correlation between nurse managers' knowledge and role with staff nurses' level of satisfaction and motivation. There is significant correlation between nurse managers' total level of knowledge and role with total staff nurses' level of satisfaction and motivation at $(\mathrm{p} \leq$ $0.05)$. 
Table (1): Distribution of study subjects according to their personal characteristics.

\begin{tabular}{|c|c|c|c|c|}
\hline \multirow[t]{2}{*}{ Variable } & \multicolumn{2}{|c|}{$\begin{array}{c}\text { Nurse } \\
\text { managers } \\
(\mathbf{n}=\mathbf{3 0})\end{array}$} & \multicolumn{2}{|c|}{$\begin{array}{c}\text { Staff } \\
\text { nurses } \\
(\mathbf{n}=\mathbf{1 8 3})\end{array}$} \\
\hline & $\mathbf{N}$ & $\%$ & $\mathbf{N}$ & $\%$ \\
\hline \multicolumn{5}{|l|}{$\overline{\text { Age }}$} \\
\hline $20-25$ & - & - & 161 & 88.0 \\
\hline $30-35$ & 6 & 20.0 & 22 & 12.0 \\
\hline$\geq 40$ & 24 & 80.8 & - & - \\
\hline Mean \pm SD & \multicolumn{2}{|c|}{$1.49 \pm 40.0$} & \multicolumn{2}{|c|}{$2.99 \pm 25.45$} \\
\hline \multicolumn{5}{|l|}{ Years of experience } \\
\hline$<5$ & 0 & 0.0 & 79 & 43.1 \\
\hline $5-10$ & 21 & 70.0 & 90 & 49.2 \\
\hline$>10$ & 9 & 30.0 & 14 & 7.7 \\
\hline Mean \pm SD & \multicolumn{2}{|c|}{$2.19 \pm 7.63$} & \multicolumn{2}{|c|}{$2.38 \pm 5.57$} \\
\hline \multicolumn{5}{|l|}{ Sex } \\
\hline Female & 30 & 100 & 151 & 82.5 \\
\hline Male & - & - & 32 & 17.5 \\
\hline \multicolumn{5}{|l|}{ Marital status } \\
\hline Married & 30 & 100 & 170 & 92.8 \\
\hline Single & - & - & 13 & 7.2 \\
\hline Others & - & - & - & - \\
\hline \multicolumn{5}{|l|}{ Unit } \\
\hline$\overline{\mathrm{CCU}}$ & 6 & 20 & 43 & 23.5 \\
\hline Open heart surgery & 7 & 23.3 & 29 & 15.8 \\
\hline Cardiac catheterization & 8 & 26.7 & 37 & 20.2 \\
\hline Emergency & 5 & 16.7 & 24 & 13.1 \\
\hline Inpatient & 4 & 13.3 & 50 & 27.3 \\
\hline \multicolumn{5}{|l|}{ Qualification } \\
\hline Diploma & 4 & 13.4 & 58 & 31.7 \\
\hline Associate degree & - & - & 32 & 17.5 \\
\hline Bachelor & 26 & 86.6 & 69 & 37.7 \\
\hline Master & - & - & 8 & 4.4 \\
\hline Diploma degree & - & - & 16 & 8.7 \\
\hline \multicolumn{5}{|c|}{$\begin{array}{l}\text { Attendance of training program about } \\
\text { performance appraisal }\end{array}$} \\
\hline Not attend & 30 & 100 & - & - \\
\hline
\end{tabular}




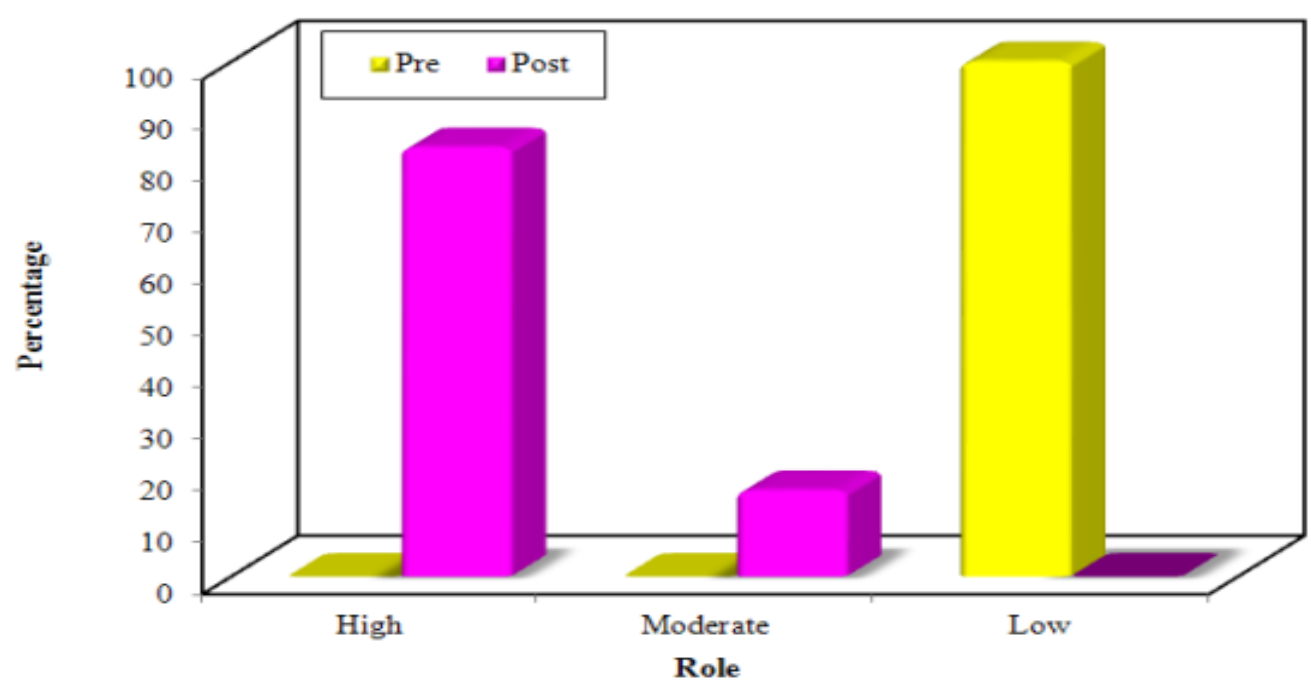

Figure (1): Levels of nurse managers' overall role in managing performance appraisal during COVID- 19 pre and post program implementation.

Table (2): Levels of nurse managers role subscales in managing performance appraisal during COVID- 19 pre and post program implementation $(n=30)$

\begin{tabular}{|c|c|c|c|c|c|c|c|c|}
\hline \multirow{3}{*}{ Role subscales } & & \multicolumn{6}{|c|}{$\begin{array}{c}\text { Levels of nurse managers' role in managing } \\
\text { performance appraisal }\end{array}$} & \multirow{3}{*}{ Test of sig } \\
\hline & & \multicolumn{3}{|c|}{ Pre } & \multicolumn{3}{|c|}{ Post } & \\
\hline & & High & Moderate & Low & High & Moderate & Low & \\
\hline \begin{tabular}{|c|} 
Creating positive \\
environment for appraisal \\
during COVID 19
\end{tabular} & $\%$ & - & - & $\begin{array}{l}30 \\
100\end{array}$ & $\begin{array}{l}20 \\
66.7\end{array}$ & $\begin{array}{c}6 \\
20\end{array}$ & $\begin{array}{c}4 \\
13.3\end{array}$ & $\begin{array}{l}17.191 \\
<0.001 *\end{array}$ \\
\hline $\begin{array}{c}\text { Planning the performance } \\
\text { appraisal during COVID } 19\end{array} \mid$ & $\mathrm{N}$ & - & - & $\begin{array}{l}30 \\
100\end{array}$ & $\begin{array}{l}23 \\
76.7\end{array}$ & $\begin{array}{c}7 \\
23.3\end{array}$ & - & $\begin{array}{l}29.589 \\
<0.001 *\end{array}$ \\
\hline $\begin{array}{c}\text { Performance review during } \\
\text { COVID } 19\end{array}$ & $\%$ & - & - & $\begin{array}{l}30 \\
100\end{array}$ & $\begin{array}{l}24 \\
80\end{array}$ & $\begin{array}{c}5 \\
16.7\end{array}$ & $\begin{array}{c}1 \\
3.3\end{array}$ & $\begin{array}{l}39.091 \\
<0.001 *\end{array}$ \\
\hline
\end{tabular}

*: Statistically significant at $\mathbf{p} \leq \mathbf{0 . 0 5}$ 


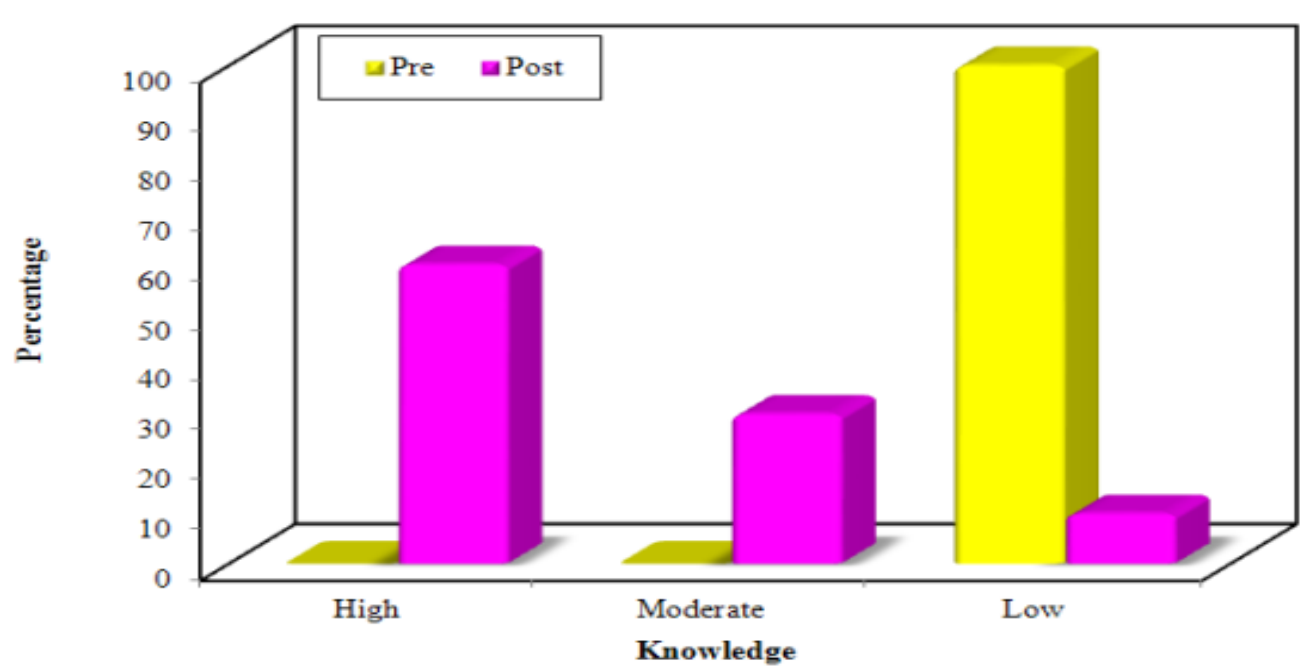

Figure (2): Nurse managers' total knowledge levels about performance appraisal pre and post program implementation

Table (3): Nurse managers' knowledge levels about performance appraisal pre and post program implementation $(\mathbf{n}=\mathbf{3 0})$

\begin{tabular}{|c|c|c|c|c|c|c|c|c|}
\hline \multirow{2}{*}{\multicolumn{2}{|c|}{$\begin{array}{l}\text { Performance appraisal } \\
\text { knowledge main items }\end{array}$}} & \multicolumn{6}{|c|}{ Level of nurse managers' knowledge } & \multirow{2}{*}{$\begin{array}{l}\text { test } \\
\text { of sig }\end{array}$} \\
\hline & & High & Moderate & Low & \begin{tabular}{|l|} 
High \\
\end{tabular} & Moderate & Low & \\
\hline Basic concepts & $\begin{array}{l}\mathrm{n} \\
\%\end{array}$ & $\begin{array}{l}- \\
-\end{array}$ & $\begin{array}{l}- \\
-\end{array}$ & $\begin{array}{l}30 \\
100\end{array}$ & $\begin{array}{c}20 \\
66.7\end{array}$ & $\begin{array}{c}10 \\
33.3\end{array}$ & $\begin{array}{l}- \\
-\end{array}$ & $\begin{array}{l}12.072^{*} \\
\mathrm{p}<0.001^{*}\end{array}$ \\
\hline Purpose & $\begin{array}{l}\mathrm{n} \\
\%\end{array}$ & $\begin{array}{c}1 \\
3.3\end{array}$ & $\begin{array}{l}- \\
-\end{array}$ & $\begin{array}{c}29 \\
96.7\end{array}$ & $\begin{array}{c}19 \\
63.3\end{array}$ & $\begin{array}{c}6 \\
20\end{array}$ & $\begin{array}{c}5 \\
16.6\end{array}$ & $\begin{array}{c}10.428^{*} \\
\mathrm{p}<0.001^{*}\end{array}$ \\
\hline Principles & $\begin{array}{l}\mathrm{n} \\
\%\end{array}$ & - & $\begin{array}{l}- \\
-\end{array}$ & $\begin{array}{l}30 \\
100\end{array}$ & $\begin{array}{c}19 \\
63.3\end{array}$ & $\begin{array}{c}11 \\
36.6\end{array}$ & $\begin{array}{l}- \\
-\end{array}$ & $\begin{array}{l}12.425^{*} \\
\mathrm{p}<0.001^{*}\end{array}$ \\
\hline
\end{tabular}




\begin{tabular}{|c|c|c|c|c|c|c|c|c|}
\hline \multirow{3}{*}{\multicolumn{2}{|c|}{$\begin{array}{l}\text { Performance appraisal } \\
\text { knowledge main items }\end{array}$}} & \multicolumn{6}{|c|}{ Level of nurse managers' knowledge } & \multirow{3}{*}{$\begin{array}{l}\text { test } \\
\text { of sig }\end{array}$} \\
\hline & & \multicolumn{3}{|c|}{ Pre } & \multicolumn{3}{|c|}{ Post } & \\
\hline & & High & Moderate & Low & High & Moderate & Low & \\
\hline Methods & $\%$ & - & $\begin{array}{c}2 \\
6.7\end{array}$ & $\begin{array}{c}28 \\
93.3\end{array}$ & $\begin{array}{l}21 \\
70\end{array}$ & $\begin{array}{l}9 \\
30\end{array}$ & - & $\begin{array}{c}9.898^{*} \\
\mathrm{p}<0.001^{*}\end{array}$ \\
\hline $\begin{array}{l}\text { Strategies to manage } \\
\text { appraisal during COVID } \\
19\end{array}$ & $\%$ & - & - & $\begin{array}{l}30 \\
100\end{array}$ & $\begin{array}{c}23 \\
76.6\end{array}$ & $\begin{array}{c}7 \\
23.3\end{array}$ & - & $\begin{array}{c}19.507^{*} \\
\mathrm{p}<0.001^{*}\end{array}$ \\
\hline Limitation & $\mathrm{n}$ & $\begin{array}{c}1 \\
3.3\end{array}$ & - & $\begin{array}{c}29 \\
96.7\end{array}$ & $\begin{array}{c}20 \\
66.6\end{array}$ & $\begin{array}{r}10 \\
33.3\end{array}$ & - & $\begin{array}{l}12.775^{*} \\
\mathrm{p}<0.001^{*}\end{array}$ \\
\hline
\end{tabular}

Table (4): Levels of staff nurses' satisfaction and motivation pre and post program implementation $(n=183)$

\begin{tabular}{|c|c|c|c|c|c|c|c|c|}
\hline & & \multicolumn{6}{|c|}{ Levels } & \multirow[b]{3}{*}{ Test of sig } \\
\hline & & \multicolumn{3}{|c|}{ Pre } & \multicolumn{3}{|c|}{ Post } & \\
\hline & & High & Moderate & Low & High & Moderate & Low & \\
\hline \multirow{2}{*}{ Staff nurses' motivation } & $\mathrm{N}$ & 23 & 10 & 150 & 118 & 44 & 21 & 42.107 \\
\hline & $\%$ & 12.66 & 5.56 & 81.96 & 64.4 & 24.3 & 11.3 & $<0.001^{*}$ \\
\hline \multirow{2}{*}{ Staff nurses' satisfaction } & $\mathrm{N}$ & 11 & 6 & 166 & 120 & 30 & 33 & 20.894 \\
\hline & $\%$ & 6 & 3.3 & 90.7 & 65.57 & 16.39 & 18.04 & $<0.001 *$ \\
\hline
\end{tabular}


Table (5): Correlation between nurse managers' knowledge and role with staff nurses' level of satisfaction and motivation

\begin{tabular}{|c|c|c|c|c|c|}
\hline & & & \multicolumn{3}{|c|}{ Staff nurses' level of satisfaction and motivation } \\
\hline & & & Nurses' motivation & $\begin{array}{c}\text { Nurses' } \\
\text { satisfaction }\end{array}$ & Overall \\
\hline \multirow{14}{*}{ 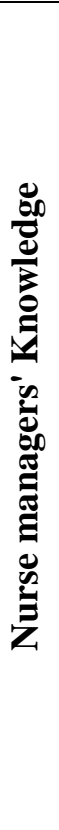 } & \multirow{2}{*}{ Basic concepts } & $\mathrm{R}$ & 0.232 & 0.311 & 0.258 \\
\hline & & $\mathrm{P}$ & 0.218 & 0.094 & 0.169 \\
\hline & \multirow{2}{*}{ Purpose } & $\mathrm{R}$ & 0.513 & 0.391 & $0.539^{*}$ \\
\hline & & $\mathrm{P}$ & $0.004^{*}$ & $0.033^{*}$ & $0.002^{*}$ \\
\hline & \multirow{2}{*}{ Principle } & $\mathrm{R}$ & 0.092 & 0.120 & 0.155 \\
\hline & & $\mathrm{P}$ & 0.629 & 0.529 & 0.413 \\
\hline & \multirow{4}{*}{$\begin{array}{r}\text { Strategies to manage appraisal } \\
\text { during COVID } 19\end{array}$} & $\mathrm{R}$ & 0.464 & 0.532 & $0.505^{*}$ \\
\hline & & $\mathrm{P}$ & $0.010^{*}$ & $0.002^{*}$ & $0.004^{*}$ \\
\hline & & $\mathrm{R}$ & 0.527 & 0.501 & $0.419^{*}$ \\
\hline & & $\mathrm{P}$ & $0.003^{*}$ & $0.005^{*}$ & $0.021^{*}$ \\
\hline & \multirow{2}{*}{ Limitation } & $\mathrm{R}$ & 0.125 & 0.238 & 0.128 \\
\hline & & $\mathrm{P}$ & 0.509 & 0.205 & 0.499 \\
\hline & \multirow{2}{*}{ Overall knowledge } & $\mathrm{R}$ & 0.726 & 0.768 & $0.792^{*}$ \\
\hline & & $\mathrm{P}$ & $<0.001^{*}$ & $<0.001^{*}$ & $<0.001^{*}$ \\
\hline \multirow{8}{*}{ 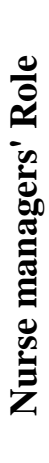 } & \multirow{2}{*}{$\begin{array}{r}\text { Creating positive environment for } \\
\text { appraisal during COVID } 19\end{array}$} & $\mathrm{R}$ & 0.435 & 0.430 & 0.597 \\
\hline & & $\mathrm{P}$ & $0.016^{*}$ & $0.018^{*}$ & $0.001 *$ \\
\hline & \multirow{2}{*}{$\begin{array}{r}\text { Planning the performance appraisal } \\
\text { during COVID } 19\end{array}$} & $\mathrm{R}$ & 0.206 & 0.182 & 0.138 \\
\hline & & $\mathrm{P}$ & 0.275 & 0.336 & 0.467 \\
\hline & \multirow{3}{*}{$\begin{array}{r}\text { Performance review during COVID } \\
19\end{array}$} & $\mathrm{R}$ & 0.286 & 0.327 & 0.311 \\
\hline & & $\mathrm{P}$ & 0.125 & 0.078 & 0.095 \\
\hline & & $\mathrm{R}$ & $0.414^{*}$ & $0.474^{*}$ & $0.406^{*}$ \\
\hline & Overall role & $\mathrm{P}$ & $0.023^{*}$ & $0.008^{*}$ & $0.026^{*}$ \\
\hline
\end{tabular}

r: Pearson coefficient

*: Statistically significant at $\mathrm{p} \leq 0.05$ 


\section{Discussion}

The current realities of coronavirus inspire all sectors to rethink on how to evaluate performance of their staff especially there is a need for new skills, competences required from all staff to steer today's changing workplace priorities (23). Performance appraisal become a challenging task required from nurse managers to identify staff nurses' strengths, areas of improvement and motivate them to perform to their full potential ${ }^{(24)}$. So, our study intended to explore effect of educational program about nurse managers' performance appraisal during COVID19 on staff nurses' satisfaction and motivation

Awareness of nurse managers of performance appraisal is very important for improving quality of healthcare service (18). But preprogram implementation, our result revealed that all nurse managers had low level in their role in managing performance appraisal during COVID-19 and low level in total knowledge. This is result can be explained by that fact that none of nurse managers attended any previous training program about performance appraisal. Nurse managers did not have sufficient knowledge about basic concept, principle, method, limitations, and strategies used to appraise staff during COVIDE 19. This is result agreed with Bigdeli, et al, (2019) (25) who found that the major problems in performance appraisal returned to inadequate education of appraisers and lack of appraisal guidelines. Also, King, (2020) ${ }^{\text {(26) }}$ mentioned that appraisers need to provide staff with appropriated feedback about their performance. Sippyand and Varma (2014) (27), Nikpeyma et al (2014) ${ }^{(28)}$ and Najafi et al, (2011) (29) recommended about importance of training program for the appraiser to reach the optimal level of performance.

Post program implementation the present study result supported our first hypothesis that after implementing educational program, it is expected that managing performance appraisal during COVID 19 by nurse managers will be improved. The study result showed significance improvement in nurse managers role and knowledge post program implementation. Nurse managers ability to review performance, planning the performance appraisal and creating positive environment during COVID 19 for performance appraisal increased. Also, they had high level of knowledge 
especially for strategies used to manage appraisal during COVID- 19 and methods of appraisal. Celik, (2014) ${ }^{(30)}$ result disagreed with our result and found that training program done for managers about performance appraisal didn't yield any significant differences and rationalized this when there is need to change evaluation behavior, this require more time and more experience.

Present study result revealed that preprogram, majority of staff nurses had low level of satisfaction with performance appraisal and motivation. This result may be due to nurse managers based on old form of performance appraisal that is present in hospital with no consideration to any changing occurs during COVID19. Vidya and Kothai, $\left(2020{ }^{(31)}\right.$ agreed with our result and found that the used performance appraisal system was ineffective because the criteria used in measuring performance not clearly defined. Najafi et al, (2010) ${ }^{(32)}$ result indicated that appraisal methods in the health care system are not effective and do not have an influence on the appraisal improvement. Also, Bultoand Markos, $\mathbf{( 2 0 1 7}^{(\mathbf{3 3})}$ found poor implementation of performance appraisal. Result supported with Alyand El-Shanawany (2016) (16) who found that nurses' dissatisfaction with performance appraisal process and less motivated in their work. Also, Aly et al, (2020) ${ }^{(34)}$ and Saad, (2014) ${ }^{(35)}$ found that studied sample had low satisfaction about performance appraisal. In contrast Chaponda, (2014) ${ }^{(36)}$ revealed that respondents were satisfied and motivated with appraisal system used.

Post program implementation, the result showed that around two third of staff nurses had high level of satisfaction with performance appraisal and motivation that supported the second hypothesis of our study. This is because nurse managers' role in performance appraisal begin to be improved especially their ability to manage performance appraisal during COVID 19 post acquired knowledge and training during program. This agreed with Kaushik and Arora (2020) ${ }^{(1)}$ who stated that at time of COVID- 19 its necessary for managers to redefine their expectations about job done. Christodoulou et al, (2020) $)^{(37)}$ recommended about redesigning the performance appraisal system to be more effective..

Result of study revealed significant correlation between total nurse managers' level of knowledge and role with total 
staff nurses' level of satisfaction and motivation. This is because staff nurses enjoy and exert effort in their work when nurse managers create positive work environment for appraisal. Managers explain to staff nurses what is expected from them and what should do to achieve high performance. This agreed with Bulto and Markos, (2017) (33) who found positive and significant relationship between performance appraisal system and employee motivation. Abed and EL Banan (2016) (38) found significant correlation between quality of performance appraisal process and job satisfaction. Schub and Mennella (2018) (24) mentioned that after conducting performance appraisals, the nurse will demonstrate motivation to maintain or improve performance.

\section{Conclusion}

Educational program for nurse managers on performance appraisal during COVID 19 play a vital role in increasing staff nurses' satisfaction and motivation that help in improving their performance, as there is a statistically significant correlation between total nurse managers' total level of knowledge and role with staff nurses' level of satisfaction and motivation.

\section{Recommendation}

\section{For hospital administration}

- Modify performance appraisal forms to adapt to any changing that occurs in environment or organization, to maintain relevance and effectiveness.

- Provide educational programs for nurse managers continuously on performance appraisal and strategies that motivate staff nurses

- Receive continuous feedback from staff nurses about their satisfaction with present performance appraisal system.

\section{For nurse manager}

- Inform staff nurses about any changing in appraisal form.

- Provide supportive environment by avoiding criticism to staff performance and encourage good discussion and communication.

- Attend workshop or training programs on performance appraisal.

Further research: effect of application of performance appraisal at COVID 19 on patient safety. 


\section{References:}

1- Kaushik N, Arora P. Performance appraisal in the era of new normal.

Journal of Technology Management for Growing Economies. 2020; 11(1): $11-15$.

2- Aquilia A, Grimley K, Jacobs B, Kosturko M, Mansfield J, Mathers Ch, Parniawski P, Wood L, Niederhauser V. Nursing leadership during COVID-19: Enhancing patient, family and workforce experience. Patient Experience Journal. 2020; 7 (2): 136-143.

3- O'Connell B. How Managers Are Handling Performance Reviews During the COVID-19 Pandemic. 2020. Available at: https://www.shrm. org/resourcesandtools/hr

4- Gupta K. V. Impact on appraisal during COVID 19. People matter digital magazine. 2020; (11):11.

5- Deligiannis N. Managing staff appraisals during COVID-19. Hays recruiting experts worldwide. 2020. Available at: https://www.hays.com. au/blog//blogs/managing-staffappraisals-during-covid-19

6- Bekele A Z, Shigutu AD, Tensay AT. The effect of employees' perception of performance appraisal on their work outcomes. Psychology. 2014; 2 (1): 137-73.

7- Mathew U, Johnson J. Impact of performance appraisal and work motivation on work performance of employee: With special reference to a multi-specialty hospital in Kerala. IOSR Journal of Business and Management. 2015;17(6):21-24.

8- Puranik S, Choudhar GB. A study on employee performance appraisal in health care. Asian Journal of Management Sciences. 2014; 2 (3): 59-64.

9- Karimi R, Malik M, Hussain S. Examining the relationship of performance appraisal system and employee satisfaction' International Journal of Business and Social Science. 2011; 2 (22): 243-247.

10-Chartered Management Institute. Conducting a Performance Appraisal. 2014.https://www.managers.org.uk/ / media/Angela-Media

11-Malik MS, Aslam S. Performance appraisal, and employee's motivation: A comparative analysis of telecom industry of Pakistan. Pakistan Journal of Social Sciences (PJSS). 2013; 33 (1): $179-89$. 
12- Ojokuku RM. Effect of performance appraisal system on motivation and performance of academics in Nigerian public universities. Australian Journal of Business and Management Research. 2013; 3 (3) :20-28.

13-Balani, A. Covid-19: What About The Appraisals? Available at: http://bw people.businessworld.in/article/Covid19-What-About-The- Appraisals-/3103-2020-187762/2020.

14-Adam S, Zahra S, Ting C, Chor C, Khare Y, Harky A COVID-19 pandemic and its impact on service provision: A cardiology prospect. Acta Cardiologic. 2020. Doi: https://doi. org/10.1080/00015385.2020.1787636.

15- Katz J, Shashank S, David N, Anne G. Covid 19 and disruptive modification to cardiac critical care delivery. Journal of the American college of cardiology. 2020;76(1):72-84.

16- Aly N, El-Shanawany S. The influence of performance appraisal satisfaction on nurses' motivation and their work outcomes in critical care and toxicology units. European Scientific Journal. 2016; 12 (20): 119-135.

17-Alvear J, David J. Manager's guide for performance appraisal. Fast Facts Resources for Nursing Home
Professionals. 2006; 2: 1-2. Available at: https://www.chcf.org/wp

18-Moradi T, Mehraban M, Moeini M. Comparison of the perception of managers and nursing staff toward performance appraisal. Iranian Journal of Nursing and Midwifery Research. 2017; 22(2):128-134.

19-Saeedi Z, Nikpeyma N, Azargashb E , Majd H. Problems of clinical nurse performance appraisal system: A qualitative study. Asian Nursing Research. 2014; 8(1):15-22.

20-Aggarwal S, Thakur G. Techniques of performance appraisal- A review. International Journal of Engineering and Advanced Technology (IJEAT). 2013; 2(3): 617-621.

21- Warr P. B, Clapperton G. The joy of work? Jobs, happiness and you. Rouletedge /taylor and fraccais group, new York, USA.2010.

22- Cameron J, Pierce WD. Reinforcement, reward, and intrinsic motivation: A meta-analysis. Review of Educational Research. 1994; 64: $363-423$.

23-Falcone P. Amending Your Performance Review Template for the COVID-19 Pandemic. 2020. 
Available at: https://www.shrm.org/ resourcesandtools/hr-topics/people managers/pages/amendingperformance-

24-Schub E, Mennella H. Employee Performance Appraisals: Conducting. 2018. Available at: https://www. ebscohost.com/assets

25-Bigdeli A, Mehraban M, Namnabati M. The effect of the appraisal interview on nurses' performance in neonatal intensive care units. Iran Journal Nurs Midwifery Res. 2019; 24 (6): 428-431.

26-King S. Employees Lived Experiences with the Performance Appraisal System. Published Doctoral Thesis, College of Management and Technology, Walden University. 2020.

27-Sippy N, Varma Sh. Performance appraisals systems in the hospital sector $-\mathrm{A}$ research based on hospitals in Kerala. International Journal of Business Management and Research. 2014; (4)1: 97-106.

28-Nikpeyma N, Abed_Saeedi Z, Azargashb, E, Alavi_Majd H. Problems of clinical nurse performance appraisal system: A qualitative study. Asian Nursing Research. 2014; 8(1): 15-22.

29- Najafi L, Hamidi Y, Ghiasi M, Shahhoseini R, Emami, $\mathrm{H}$. Performance evaluation and its effects on employees' job motivation in Hamedan city health centers. Australian Journal of Basic and Applied Sciences.2011; 5(12):17611765.

30-Celik D. Enabling more objective performance appraisal: A training program model of pinpointing. Procedia-Social and Behavioral Sciences. 2014; 150: 794-802.

31-Vidya D, Kothai P. A Study on the effectiveness of performance management system. Mukt Shabd Journal. 2020; 9 (4): 218-222.

32-Najafi L, Hamidi Y, Vatankhah S, Purnajafet A. Performance appraisal and its effects on employees' motivation and job promotion. Australian Journal of Basic and Applied Sciences. 2010; 4(12): 60526056.

33- Bulto, L, Markos S. Effect of performance appraisals system on employee motivation. Prestige International Journal of Management 
and IT-Sanchayan. 2017; 6 (2), 2536.

34- Aly F, Abed F, Mohamed N. Impact of organizational justice on performance appraisal process and commitment among staff nurses at an oncology hospital. Med. Journal. Cairo Univ. 2020; 88 (2): 939-945.

35- Saad S. Investigating the effectiveness of the performance appraisal process in the Egyptian tourism companies. Journal of Association of Arab Universities for Tourism and Hospitality. 2014; 11 (2): $111-121$.

36-Chaponda N. The Effect of Performance Appraisal on Employee Motivation: A Survay of Slum Based Non-Governmental Organization in Nairobi. Published Master Thesis. Chandaria School of Business. United states International University-Africa.2014.

37- Christodoulou S, Louca A, Petasis A. Employees perception on performance appraisal effectiveness in the Cyprus public sector (EAC). International Journal of Human Capital Management. 2020; 4 (1): 26-41. 38-Abed F, EL-Banan S. The relationship between quality of performance appraisal process and nurses job satisfaction as perceived by staff nurses at a selected hospital. International Journal of Nursing Didatics. 2016; 6 (12): 15-21. 